\title{
Post-Infectious Acute Glomerulonephritis in Child: Epidemiological, Clinical and Evolutionary Aspects in Gabriel Touré Teaching Hospital in Mali
}

\author{
Mariam Sylla1, Fatoumata Dicko-Traoré ${ }^{1 *}$, Abdoul Karim Doumbia1, Aminata Coulibaly1, \\ Abdoul Aziz Diakité1, Modibo Sangaré2, Pierre Togo¹, Fousseyni Traoré1, Amadou Touré1, \\ Djènèba Konaté1, Karamoko Sacko', Belco Maiga1, Fatoumata Léonie Diakité1, \\ Lala N'Drainy Sidibé1, Mohamed Elmouloud Cissé1, Adama Dembélé1, Hawa Diall'1, \\ Oumar Coulibaly1, Ibrahim Hamadou1, Leyla Maiga1, Issiaka Koné1, Boubacar Togo1, \\ Toumani Sidibé ${ }^{1}$
}

${ }^{1}$ Department of Pediatrics, CHU Gabriel Touré, Bamako, Mali

${ }^{2}$ Faculty of Medecine and Odontostomatology, Bamako, Mali

Email: ^fatdickoped@gmail.com

How to cite this paper: Sylla, M., Dicko-Traoré, F., Doumbia, A.K., Coulibaly, A., Diakité, A.A., Sangaré, M., Togo, P., Traoré, F., Touré, A., Konaté, D., Sacko, K., Maiga, B., Diakité, F.L., Sidibé, L.N., Cissé, M.E., Dembélé, A., Diall, H., Coulibaly, O., Hamadou, I., Maiga, L., Koné, I., Togo, B. and Sidibé, T. (2018) Post-Infectious Acute Glomerulonephritis in Child: Epidemiological, Clinical and Evolutionary Aspects in Gabriel Touré Teaching Hospital in Mali. Open Journal of Pediatrics, 8, 366-374.

https://doi.org/10.4236/ojped.2018.84036

Received: November 25, 2018

Accepted: December 23, 2018

Published: December 26, 2018

Copyright $\odot 2018$ by authors and Scientific Research Publishing Inc. This work is licensed under the Creative Commons Attribution International License (CC BY 4.0).

http://creativecommons.org/licenses/by/4.0/ (c) (i) Open Access

\section{Abstract}

Introduction: Acute post-infectious glomerulonephritis (APIGN) can be serious due to its complications that still occur in our countries. In this work, we aimed to study the epidemiological, clinical, biological and evolutionary aspects of APIGN. Patients and methods: We conducted a retrospective, descriptive study from January $1^{\text {st }}, 2015$ to December $31^{\text {st }}, 2017$ in the pediatric ward of the Gabriel Touré Teaching Hospital in Bamako. All children hospitalized for APIGN were included. Results: In two years, we included 10 children aged 7 years old on average; all from low socioeconomic backgrounds. The sex ratio was 1.5 . On average, the children spent 15.8 days before our consultation. Edema was the main reason for consultation. We found a history of infection and high blood pressure in 30\% each, and renal failure in $10 \%$ of the children. Hematuria and proteinuria were detected in $100 \%$ and $90 \%$, respectively. Hypocomplementemia was observed in $66.6 \%$. One third of the children had a positive antistreptolysin $O$. The average duration of hospital stay was 11.2 days. The evolution was favorable in $90 \%$. Kidney failure was the leading cause of death. Conclusion: Acute post-infectious glomerulonephritis is still a reality in our context. Emphasis should be put on its prevention by improving the hygienic conditions, detection and the management of infections. 


\section{Keywords}

Glomerulonephritis, Infection, Pediatrics, Mali

\section{Introduction}

Acute post-infectious glomerulonephritis (APIGN) is defined by a non suppurative acute inflammatory aggression with glomerular predominance [1]. APIGN is the second infantile nephropathy after nephrotic syndrome [2] [3] [4]. APIGN is mostly caused by group A $\beta$-hemolytic streptococcus, but any infectious agent (bacteria, virus, fungal, parasite) can be causative [1] [5].

The incidence of APIGN is not well known due to the frequency of infra-clinical forms [1]. APIGN is in significant decrease in countries where health coverage and hygiene conditions are sufficient [1] [6] [7] [8]. Proper management of streptococcal infections resulted in extreme rarity of the condition in France [9]. APIGN still exists in Africa and remains an important cause of renal lesions in children [2]. APIGN can be severe and may lead to a fatal renal insufficiency in children [3] [6]. In Mali, urinary tract pathology represents $1 \%$ of all hospital stays in the pediatrician department of the University hospital Gabriel Toure, the national reference structure [3]. APIGN is the third most frequent pathology (12.5\%) behind nephrotic syndrome (43.1\%) and urinary infection (22.2\%) [3]. Despite its frequency, no study was yet carried out to describe the profile of children with APIGN. This work aimed to determine the epidemiologic, clinical, biological and evolutive characteristics of APIGN in the Malian context.

\section{Patients and Methods}

We conducted a 2-year retrospective study from January $1^{\text {st }}, 2015$ to December $31^{\text {st }}, 2017$ in the pediatrician department of the Gabriel Touré teaching hospital in Bamako, the capital city of Mali. Our department is the highest reference structure in the country. Its ensure the care of either children referred from all over the country at every level of the national health pyramid or those accompanied by their parents from downtown and suburban areas of Bamako.

We reviewed the medical charts of children aged 1 month to 15 years old, hospitalized for APIGN. The variables studied were: socio-demographic characteristics (sex, age, socioeconomic level), clinical (weight, signs, complications), evolutionary (immediate becoming).

The clinical operational definition we adopted for APIGN was the presence of edema associated with at least another element of nephritic syndrome (hematuria, proteinuria, high blood pressure, or oliguria).

Socio-economic conditions were appreciated with the Chauliac $\mathrm{M}$ and $\mathrm{Ag}$ Bendech method [10] [11]. This method is based on the residency, type of housing, profession of the child's father, and the family earnings. This allows us to 
classify the socio-economic ranking: high, intermediate and low.

Oliguria was considered when the diuresis was to $2 \mathrm{~mL} / \mathrm{kg} / \mathrm{hour}$ [12].

High blood pressure was defined when the diastolic and systolic blood pressures were $\geq 95$ percentile [13].

Proteinuria was defined by a rate superior to $150 \mathrm{mg}$ /day and was nephrotic when superior to $50 \mathrm{mg} / \mathrm{kg} /$ day.

Complement C3 fraction was labeled low when inferior to $0.82 \mathrm{~g} / \mathrm{L}$, elevated creatininemia when superior a $110 \mu \mathrm{mol} / \mathrm{L}$, elevated uremia when superior to $7.6 \mathrm{mmol} / \mathrm{L}$ and anti-streptolysin (ASLO) was positive when superior to $200 \mathrm{UI} / \mathrm{mL}$ [12].

Creatinine clearance was not determined and no renal biopsy was performed.

Anemia was defined according the WHO [14]: Hemoglobin inferior to 11 $\mathrm{g} / \mathrm{dL}$ before 5 years old, inferior to $11.5 \mathrm{~g} / \mathrm{dL}$ between 5 and 11 years old, inferior to $12 \mathrm{~g} / \mathrm{dL}$ after 11 years old. Anemia was considered severe at the $\mathrm{Hb}<7 \mathrm{~g} / \mathrm{dL}$ and $<8 \mathrm{~g} / \mathrm{dl}$ before and after 5 years old, respectively.

\section{Results}

During the 2-year study period, 6087 patients were hospitalized in the above mentioned department. The hospital frequency of APIGN was $0.16 \%(10 / 6087)$.

The sex ratio was 1.5 (six boys for three girls). The mean age was 7 years old with the extremes of $1-13$ years old. Children less than 5 years old and those more than 10 years old represented $30 \%$ and $40 \%$, respectively. All patients were from a low socio-economic ranking. The disease onset was more likely to happen in winter $(60 \%)$.

Oedema was limited to the face $(20 \%)$ or generalized $(80 \%)$ and was the most frequent reason for outpatient visits. About one third of the patients (30\%) had a history of infection such as suppurative otitis, pyodermitis, and abscess of the upper limb preceding the onset of the APIGN. The delay period between the onset and the outpatient visit varied from 4 to 37 days with a mean of 15.8 days.

All the patients had modified urine color and $90 \%$ of them had hematuria evidenced by urine sticks. Three patients (30\%) had high blood pressure at the admission. Convulsive crisis revealed the disease in one patient. One patient had oliguria; $30 \%$ had fever; and 20\% had pneumonia.

Proteinuria was found in $90 \%$ of the patients, and was mostly non nephrotic with $338.88 \mathrm{mg} / 24$ hours. Blood protein level was low in three fourth of the patients. Complement C3 was lower in 4 out of six patients (66.66\%) who had its dosage. ASLO was positive in two out of three patients. A patient had oliguria with hyper-creatinemia at $731.90 \mu \mathrm{mol} / \mathrm{L}$. Two patients had creatininemia of $133 \mu \mathrm{mol} / \mathrm{L}$ and $135 \mu \mathrm{mol} / \mathrm{L}$, respectively. Uremia was concomitantly elevated with creatininemia in three patients. Uremia was normal in all the remaining patients.

Anemia was present in all the patients, but severe in only $30 \%$. The outcome was favorable in $90 \%$ of the patients with a complete regression of the oedema and the normalization of the creatininemia before the discharge from the hos- 
pital. The only complication found was kidney failure found in a child. This child passed away due to this renal insufficiency.

Water restriction and low sodium diet were prescribed in all patients. Antidiuretic treatment (furosemide) was done in $70 \%$ of patients. Antihypertensives (calcium channel blockers or converting enzyme inhibitors) have been prescribed in patients with high blood pressure.

The mean hospital stay was 11.2 days with the extremes of 6 and 42 days.

The main characteristics of patients are summarized in Table 1.

\section{Discussion}

Acute post-infectious glomerulonephritis occupies an important place among the infantile nephropathies [2] [3] [15] [16]. APIGN is the most frequent renal pathology in Nepal (37.7\%) [15], the third and fourth most frequent urinary tract pathologies in Ethiopia (12.2\%) [16] and in Cote d'Ivoire (12.9\%) [3].

The hospital frequency of APIGN is diversely appreciated in the literature. It varies from $0.16 \%$ with five per year on average to $2.65 \%$ in the pediatrician department of the Teaching Hospital of Donka, Guinea [17]. In Iran, Sepahi MA et al., collected 94 cases in six years with an annuel incidence of 15.66 [18] versus 6.66 per year in Delta State Teaching Hospitalin Nigeria in 2015 [19] and 7.7 cases per year in Congo [2] [3] [15] [16].

The divergence between these results can be explained by the definition criteria of APIGN, the study type, and the inclusion crieteria. The prevalence of APIGN is in decrease in most of the industrialized countries [5] [7] [9] [20].

Although this study is retrospective, essential limit of this work, it allowed to appreciate the characteristics of post-infectious acute glomerulonephritis in our context.

Table 1. Summary of the main characteristics of patients.

\begin{tabular}{|c|c|c|c|c|c|c|c|}
\hline Patient & Age (year old)/Sex* & $\begin{array}{c}\text { causal } \\
\text { Infection }\end{array}$ & Hématuria ${ }^{* *}$ & $\begin{array}{c}\mathrm{C} 3 \\
(\mathrm{~g} / \mathrm{L})\end{array}$ & $\begin{array}{c}\text { Creatininemia } \\
(\mu \mathrm{mol} / \mathrm{L})\end{array}$ & $\begin{array}{c}\text { Protéinuria/24 H } \\
\text { (mg/day) }\end{array}$ & Evolution \\
\hline 1 & $9 / \mathrm{F}$ & Suppurative otitis & ++++ & 1.16 & 731.90 & 799.00 & Passedaway \\
\hline 2 & $12 / \mathrm{F}$ & Limb abces & + & - & 135.00 & 26.24 & Favorable \\
\hline 3 & $6 / \mathrm{M}$ & - & ++ & - & 46.27 & 292.00 & Favorable \\
\hline 4 & $2 / \mathrm{M}$ & - & ++ & 0.34 & 53.35 & 90.00 & Favorable \\
\hline 5 & $8 / \mathrm{M}$ & - & + & 0.42 & 85.70 & 149.85 & Favorable \\
\hline 6 & $12 / \mathrm{F}$ & - & ++ & 1.48 & 33.09 & 829.87 & Favorable \\
\hline 7 & $5 / F$ & - & +++ & - & 60.13 & 379.72 & Favorable \\
\hline 8 & $13 / \mathrm{F}$ & - & + & - & 133.00 & 238.14 & Favorable \\
\hline 9 & $1 / \mathrm{M}$ & Pyodermitis & ++ & 0.52 & 62.52 & 54.00 & Favorable \\
\hline 10 & $13 / \mathrm{M}$ & - & + & 0.10 & 29.54 & 61.13 & Favorable \\
\hline
\end{tabular}

${ }^{\star}$ Sex: $\mathrm{M}=$ Male, $\mathrm{F}=$ Female; ${ }^{*}$ Hematuria appreciated with urinary sticks. 
The mean age of the patients was 7 years old similarly to the findings in many studies [7] [17] [18] [19]. Assambo-Kieli C [2] found a mean age of 12.6 years old. Most of our patients were aged $>10$ years old as compared to $30 \%$ over 14 years old in Maroc [21] allowing the author Razzouki K to suggest that APIGN was becoming a pathology of teenagers. Male predominance was found in our cohort and in many other studies [2] [5] [6] [17].

The frequency of APIGN is strongly influenced by the socio-economic status. All our patients were deprived from low socio-economic ranking. McGilUgwu also found (60\%) of such patients in Nigeria [19]. Mola K suggested that insufficient sensibilization of families and the ignorance of early alarming signs are the favoring factors of APIGN in poor neighborhood.

The lack of information on APIGN can explained the long delay of 15 days between the onset of the disease and the first outpatient visit in Mali and at the University hospital of Addis-Abeba in Ethiopia [16]. The commonest form of APIGN occurs in communities with low socio-economic status and poor hygiene conditions living in promiscuity [5]. Certain environmental factors may influence the occurrence of the causal infection of APIGN. Winter was incriminated in our study and in Guinea by Bah O [17] who suggested that frequent respiratory tract infections in winter is a possible explanation the association between APIGN and winter. Bayahia R found that APIGN is seasonal resulting from rhino-pharyngeal infections in winter and skin infections in spring [5].

We found no causal infection in $30 \%$ of the patients. In fact, in our context, causal infections are often silent or ignored. In Guinea, sore throat (60.4\%) and suppurative otitis (16.2\%) were the most frequent causal infections [17]. In India, Gunasekaran K mainly found pyo-dermitis in $80.6 \%$ and few cases of varicella and measles [22]. In Nigeria, McGilUgwu GI [19] suspected streptococcal infection in 35\%. VanDeVoorde RG [20], assumed that proper management of infections has decreased this form of APIGN worldwide in general. Two of our patients had pneumonia in which we could neither find the germ nor associate it with APIGN. In 2013, Vitaliti G [23] in Italy, reported a 3-year old infant with APIGN secondary to a Chlamydia pneumoniae pulmonary infection.

Clinically, we recruited typical presentations of APIGN as described in the literature with few exceptions due to the variability of the inclusion criteria. Oedema, often generalized, was the main reason for outpatient visit in Guinea [17], Nigeria [19] and Iran [18] similar to our study. This reinforces the feeling that only visible and worrisome signs motivate medical management in low socio-economic setting. The presence of hematuria with urines "porto", "bouillon sale", "coca" can be the revealing sign of the disease [24]. We found hematuria in $69 \%$ of the patients versus $100 \%$ in a study in Niger [19]. High blood pressure was found in one third of the patients, 39\% in the cohort of Bah O [17], over half of the patients in Nigeria [19] and in $82.4 \%$ patients in Israel [7]. Surprisingly, Sepahi MA found no cases of hematuria in Iran [18].

Proteinuria was present in $90 \%$ of our patients, but none reached a level of 
nephrotic proteinuria, an actually frequent finding in APIGN [7]. Nephrotic proteinuria in APIGN patients was reported in 54.48\% in Congo, $18 \%$ in Marocet $22.9 \%$ in Isreal. In nephrotic syndrome, which is often transient in APIGN, electrophoresis of proteins can reveal a normal or low level plasmatic protein level with hypoalbuminemia [5] [17]. Three fourth of our patients had hypoproteinemia. Thomas R [24] said, "a low grade hypoalbuminemia is typical in many inflammatory processes, but values inferior to $2 \mathrm{~g} / \mathrm{dL}$ are unusual and suggest an association of nephrotic syndrome".

Complement C3 fraction was low in two third of the patients. According to Dagan $\mathrm{R}$, hypo-complementemia was correlated to age and more frequent in older infants and teenagers [7]. Some authors viewed hypo-complementemia as a poor prognostic factor [7] [25], but others support that it is a major sign of post-streptococcal APIGN [5] [20] [24] [26]. Consequently, ASLO is elevated in the first 15 days and decreases up to becoming normal after few months [5]. To optimize the diagnostic of streptococcal infection, at least two subsequent measurements of ASLO along a simultaneous dosage of anti-DNASE B are necessary [26]. Only 30\% of our patients benefited from two dosages of ASLO with positive results for a single patient as compared to $37 \%$ positive ASLO at the University hospital in Donka, Guinea [17].

Acute renal insufficiency can reveal or complicate APIGN [5] [6] [24]. The mean creatininemia was $173.4 \mu \mathrm{mol} / \mathrm{l}$ with the extremes of $33.09 \mu \mathrm{mol} / \mathrm{l}$ and $731.90 \mu \mathrm{mol} / \mathrm{l}$ in our cohort. Renal insufficiency was diagnosed in Congo (16\%), Guinea (34.5\%) and India (20.8\%) [2] [4] [22] of APIGN patients and was identified as a poor prognostic factor [2] [22] [27] [28].

Anemia was present in $100 \%$ in our cohort and $90 \%$ in Nigeria [19]. Anemia was severe in one third of our patients comparable to $35 \%$ in Guinea [17]. Anemia by hemodilution is frequent in glomerulonephritis (GN) [24]. Nevertheless, in the presence of severe anemia, the search for another chronic cause is justified [24]. Diouf et al., reported $72 \%$ of anemia from his study in 11 French speaking African countries in 2015 [29]. Malaria is another important cause of anemia in our context [17] [29]. When the causal germ is Plasmodium malariae, anemia results in "quartane" nephropathie and membrano-proliferative GN [30].

The evolution of APIGN was favorable in $90 \%$ in our cohort and $95 \%$ in $\mathrm{Ni}$ geria [19]. Many authors consider properly managed APIGN a benign condition [5] [6] [24] regardless of the possibility of complications such as renal insufficiency [2] [21] [22] [27] [28].

\section{Conclusion}

Very rare in developed countries, APIGN still remains a reality in our context. Long delays before the medical visit are due to the scarcity of living conditions of the families. Diagnostic and management are consequently delayed. Complications are dreadful and prevention is essential. Hygiene conditions should be improved and infections should be rigorously managed in children. 


\section{Conflicts of Interest}

The authors declare no conflicts of interest regarding the publication of this paper.

\section{References}

[1] Ramdani, B., Zamd, M., Hachim, K., Soulami, K., Ezzahidy, M., Souiri, M., et al. (2012) Acute Post-Infectious Gomerulonephritis. Néphrologie \& Thérapeutique, 8 , 247-258. https://doi.org/10.1016/j.nephro.2011.11.011

[2] Assambou-Kieli, C., Moyen, G., Etokabeka, F. and Nzingoula, S. (1995)Acute Post-Infectious Gomerulonephritis: Epidemiological, Clinical and Evolutionary Aspect: About 31 Cases at the Teaching Hospital of Brazzaville. Médecine d Afrique noire, 42, 300-303.

[3] Coulibaly, P.N.A., Cissé, L., Diarrassouba, G., Egesi, M., Tia, W.M., Ouattara, G.J. and Oulai, S. (2015) Renal and Urinary Diseases of Hospitalized Children in the Pediatric Ward of the Teaching Hospital of Treichville (Abidjan). Médecine d Afrique noire, 62, 321-326.

[4] Ministry of Health and Public Hygiene of the Republic of Mali and National Directorate of Health and Gabriel Touré Teaching Hospital (2017) Activity Report of the Department of Pediatrics. $37 \mathrm{p}$.

[5] Ministry of Health of the Kingdom of Morocco (2012) Good Medical Practice Recommendations: Glomerulonephritis. 43 p.

http://nephro-maroc.com/wp-content/uploads/2016/03/guide_glomerulonephrit

[6] François-Pradier, H. (2016) Post Infectious or Infectious Glomerulonephritis. La Revue du praticien, 66, 1115-1120.

[7] Dagan, R., Cleper, R., Davidovits, M., Sinai-Trieman, L. and Krause, I. (2016) Post-Infectious Gomerulonephritis in Pediatric Patients over Two Decades: Severity-Associated Features. The Israel Medical Association Journal, 18, 336-340.

[8] Kambham, N. (2012) Post Infectious Glomerulonephritis. Advances in Anatomic Pathology, 19, 338-347. https://doi.org/10.1097/PAP.0b013e31826663d9

[9] Le-Berre, N., Filipozzi, P., Martin, L., Frimat, L. and Girerd, S. (2017) First Case Report of Streptococcus equi Subsp. Zooepidemicus Post-Infectious Acute Glomerulonephritis in France. Néphrologie \& Thérapeutique, 13, 37-41. https://doi.org/10.1016/j.nephro.2016.07.448

[10] Chauliac, M., Bricas, N., Ategbo, E.A., Amoussa, W. and Zohoun, I. (1998) Alimentaion out of the Home of Schoolchildren in Cotonou (Benin). Santé, 8, 101-108.

[11] Ag Bendech, M., Chauliac, M. and Malvy, D. (1996) Variability of Home-Based Dietary Practices of Families Living in Bamako (Mali) According to Socio-Economic Levels. Cahiers Santé, 6, 285-97.

[12] Hogg, R.J., Portman, R.J. and Milliner, D. (2000) Evaluation and Management of Proteinuria and Nephrotic Syndrome in Children: Recommandations from a Pediatric Nephrology Panel Established at the National Kidney Foundation Conference on Proteinuria, Albuminuria, Risk, Assessment, Detection, and Elimination (PARADE). Pediatrics, 105, 1242-1249. https://doi.org/10.1542/peds.105.6.1242

[13] National High Blood Pressure Education Program Working Group on High Blood Pressure in Children and Adolescent (2004) The Fourth Report on the Diagnosis, Evaluation, and Treatment of High Blood Pressure in Children and Adolescent. Pediatrics, 114, 555-576. https://doi.org/10.1542/peds.114.2.S2.555 
[14] World Health Organisation (2011) Haemoglobin Concentrations for the Diagnosis of Anaemia and Assessment of Severity. 6 p. http://www.who.int/vmnis/indicators/haemoglobin.pdf

[15] Yadav, S.P., Shah, G.S., Mishra, O.P. and Baral, N. (2016) Pattern of Renal Diseases in Children: A Developing Country Experience. Saudi Journal of Kidney Disease and Transplantation, 27, 371-376. https://doi.org/10.4103/1319-2442.178565

[16] Mola, K. and Shimelis, D. (2016) Pattern and Outcome of Renal Diseases in Hospitalized Children in TikurAnbessa Specialized Teaching Hospital, Addis Ababa, Ethiopia. Ethiopian Medical Journal, 54, 117-123.

[17] Bah, A.O., Diallo, S.B. and Kaba, M.L. (2006) Post-Infectious Acute Glomerulonephritis of the Child: Epidemiological and Clinical Aspects in the Pediatric Ward of the Donka Teaching Hospital, Conakry. Rev. Int. Sc. Méd., 8, 31-34.

[18] Sepahi, M.A., Shajari, A., Shakiba, M., Shooshtary, F.K. and Salimi, M.H. (2011) Acute Glomerulonephritis: A 7 Years Follow Up of Children in Center of Iran. Acta MedicaIranica, 49, 375-378.

[19] McGilUgwu, G.I. (2015) Acute Glomerulonephritis in Children of the Niger Delta Region of Nigeria. Saudi Journal of Kidney Disease and Transplantation, 26, 1064-1069. https://doi.org/10.4103/1319-2442.164618

[20] VanDeVoorde, R.G. (2015) Acute Poststreptococcal Glomerulonephritis: The Most Common Acute Glomerulonephritis. Pediatrics in Review, 36, 3-12. https://doi.org/10.1542/pir.36-1-3

[21] Razzouki, K., Elbouaychi, M., Bourrahouate, A., Sbihil, M. and Sab, A. (2014) Acute Post-Infectious Gomerulonephritis: Is It Still a Benigne Disease? Archives de Pédiatrie, 21, 770. https://doi.org/10.1016/S0929-693X(14)72030-5

[22] Gunasekaran, K., Krishnamurthy, S., Mahadevan, S., Harish, B.N. and Kumar, A.P. (2015) Clinical Characteristics and Outcome of Post-Infectious Glomerulonephritis in Children in Southern India: A Prospective Study. Indian Journal of Pediatrics, 82, 896-903. https://doi.org/10.1007/s12098-015-1752-0

[23] Vitaliti, G., Falsaperla, R., Giunta, L., Spataro, G., Rapisarda, V., Velardita, M., et al. (2013) Acute Glomerulonephritis in a Child with Chlamydia pneumoniae Infection: A Case Report. Case Reports in Medicine, 2013, Article ID: 570921.

[24] Thomas, R.W. (2002) An Approche to the Child with Acute Glomerulonephritis. International Journal of Pediatrics, 2002, Article ID: 426192. https://doi.org/10.1155/2012/426192

[25] Becquet, O., Pasche, J., Gatti, H., Claude, C., Abély, M., Morville, P., et al. (2010) Post-Streptococcal Glomerulonephritis in Children in French Polynesia: A 3-Year Retrospective Study. Pediatric Nephrology, 25, 275-280. https://doi.org/10.1007/s00467-009-1325-4

[26] Sen, E.S. and Ramanan, A.V. (2014) How to Use Antistreptolysin O Titre. Archives of Disease in Childhood-Education and Practice, 99, 231-238. https://doi.org/10.1136/archdischild-2013-304884

[27] Jellouli, M., Maghraoui, S., Abidi, K., Hammi, Y., Goucha, R., Naija, O., et al. (2015) Outcome of Rapidly Progressive Glomerulonephritis Post-Streptococcal Disease in Children. Néphrologie \& Thérapeutique, 11, 487-491. https://doi.org/10.1016/j.nephro.2015.04.005

[28] Piyaphanee, N., Ananboontarick, C., Supavekin, S. and Sumboonnanonda, A. (2016) Renal Outcome and Risk Factors for End-Stage Renal Disease in Pediatric Rapidly Progressive Glomerulonephritis. Pediatrics International, 59, 334-341. 
https://doi.org/10.1111/ped.13140

[29] Diouf, S., Folquet, M., Mbofung, K., Ndiaye, O., Brou, K., Dupont, C., et al. (2015) Prevalence and Determinants of Anemia in Young Children in French-Speaking Africa-Involvement of Iron Deficiency. Archives de Pédiatrie, 22, 1188-1197. https://doi.org/10.1016/j.arcped.2015.08.015

[30] Raharivelina, C., Andrianarison, L. and Rakotoarivelo, R. (2009) Un cas de glomérulonéphrite membrano-proliférative d'origine paludéenne: Néphropathie quartane? Médecine de Afrique Noire, 56, 289-393. 